CRTST, Centre for Research on Inequality,

Department of International Development, University of Oxford

\title{
Ethnicity, Religion and the State in Ghana and Nigeria: Perceptions from the Street
}

\author{
Arnim Langer and Ukoha Ukiwo \\ CRISE WORKING PAPER No. 34 \\ October, 2007
}

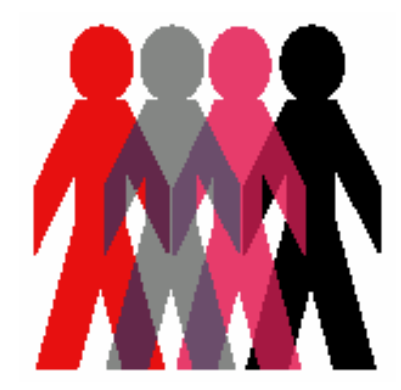




\title{
Ethnicity, Religion and the State in Ghana and Nigeria: Perceptions from the Street
}

\begin{abstract}
Objectively speaking, both Ghana and Nigeria are characterised by severe socioeconomic inequalities among their regions, ethnic groups and religions. Yet, since ultimately collective action depends on how social groups perceive the world in which they live and act, unravelling such perceptions must be a critical element in any investigation of group behaviour, including violent group mobilization. One of the preferred methods of obtaining data on these issues is through a social survey. This paper presents and analyzes survey data on how people see their own identities and their perceptions of the extent of domination of state institutions by particular ethnic or religious groups in Ghana and Nigeria. The data are drawn from perceptions surveys conducted in both countries which consisted principally of a set of structured questionnaires in which respondents answered closed-ended questions. The surveys show quite marked differences in comparative perceptions of identities and of perceptions of the state in both countries.
\end{abstract}

The authors

Arnim Langer is Research Officer in Economics and Politics, West Africa, at the Centre for Research on Inequality, Human Security and Ethnicity, Department of International Development, University of Oxford.

Email: arnim.langer@qeh.ox.ac.uk

Ukoha Ukiwo is a Research Fellow at the Centre for Advanced Social Science (CASS), Port Harcourt, Nigeria, and a Visiting Scholar at the Institute of International Studies, University of California, Berkeley, USA. He was a CRISE scholar at the Department of International Development, University of Oxford, from 2003 to 2006.

Email: uukiwo@hotmail.com 


\section{Table of Contents}

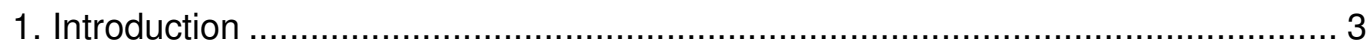

2. 'Objective' socioeconomic and political inequalities in Ghana and Nigeria............. 4

3. Ethnic and religious composition of the survey samples ................................... 8

4. The salience of different identities ................................................................. 10

5. The perceived impact of ethnicity and religion in the public sphere ..................... 12

6. Perceptions of political horizontal inequalities................................................. 17

7. Perceptions of government favouritism and discrimination ............................... 19

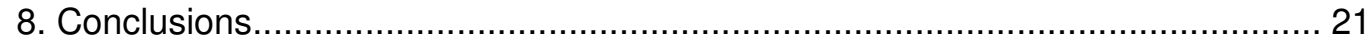

\section{List of Tables}

Table 1: Various socioeconomic indicators across Ghana's regions, $1997-1999 \ldots \ldots . .5$

Table 2: Various socioeconomic indicators across Nigeria's zones in 1995/96 ......... 5

Table 3: Ethnoregional composition of various Ghanaian governments, 1993-2005.. 6

Table 4: Zonal composition of various Nigerian cabinets, 1983-2004 ...................... 7

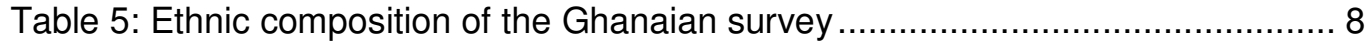

Table 6: Ethnic composition of the Nigerian survey ............................................. 8

Table 7: Religious composition of the Ghanaian survey ........................................ 9

Table 8: Religious composition of the Nigerian survey ........................................ 9

Table 9: The proportion of Ghanaian respondents according to survey location who thought that ethnicity affected someone's chances of getting .............................. 13

Table 10: The proportion of Nigerian respondents according to survey location who thought that ethnicity affected someone's chances of getting .............................. 13

Table 11: The proportion of Ghanaian respondents according to educational background and survey location who thought that ethnicity affected someone's chances of getting

Table 12: The proportion of Nigerian respondents according to educational background and survey location who thought that ethnicity affected someone's chances of getting ...

Table 13: The proportion of Ghanaian respondents according to survey location who thought that religion affected someone's chances of getting ............................... 17 Table 14: The proportion of Nigerian respondents according to survey location who thought that religion affected someone's chances of getting …............................ 17 Table 15: The proportion of Ghanaian respondents according to survey location who considered a specific state institution to be dominated by a particular group............ 18 Table 16: The proportion of Nigerian respondents according to survey location who considered a specific state institution to be dominated by a particular group ........... 18 Table 17: Perceptions of government favouritism and discrimination in Ghana according to survey location....

Table 18: Perceptions of government favouritism and discrimination in Nigeria according to survey location....

\section{List of Figures}

Figure 1: Three most important forms of self-identification in Ghana 10

Figure 2: Three most important forms of self-identification in Nigeria 


\title{
Ethnicity, Religion and the State in Ghana and Nigeria: Perceptions from the Street
}

\author{
By Arnim Langer and Ukoha Ukiwo ${ }^{1,2}$
}

\section{Introduction}

Objectively speaking, both Ghana and Nigeria are characterised by severe socioeconomic inequalities among their regions, ethnic groups and religions. Yet, since ultimately collective action depends on how social groups perceive the world in which they live and act, unravelling such perceptions must be a critical element in any investigation of group behaviour, including violent group mobilization. One of the preferred methods of obtaining data on these issues is through a social survey. This paper presents and analyzes survey data on how people see their own identities and their perceptions of the extent of domination of state institutions by particular ethnic or religious groups. The data are drawn from perceptions surveys conducted in both countries which consisted principally of a set of structured questionnaires in which respondents answered closed-ended questions. ${ }^{3}$

It is important to note that the perceptions surveys conducted in Ghana and Nigeria were not nationally representative. The results are therefore only statistically representative for the selected survey locations, but we can draw wider inferences based on the assumption that the surveyed areas are qualitatively representative of a larger part of society. In the perceptions survey conducted in Ghana, 608 randomly selected individuals of eighteen years and above were interviewed in three urban settings in the southern part of the country, namely: Accra in the Greater Accra Region, Ho in the Volta Region and Kumasi in the Ashanti Region. Ghana's 2000 Population and Housing Census provided us with precise and reliable data on the ethnic composition of these three cities. While Accra -Ghana's capital- is ethnically diverse, Ho and Kumasi are both much more ethnically homogenous. By selecting these three survey areas, we aimed to explore whether ethnic heterogeneity of communities affected the way people perceived issues related to their ethnic and religious identity. To reflect differences in size of each city, the 608 interviews were distributed as follows: Accra 306, Ho 61 and Kumasi 241.

In the Nigerian case, we selected Lagos, Nigeria's economic capital and most populous city and Kukawa, Borno State, situated on the Lake Chad basis in the north-eastern part of the country. Kukawa was the capital of the Kanem Bornu Empire and is a semi-urban area, attracting traders and artisans from different parts of the country as a result of its proximity to Lake Chad and the Nigeria, Niger and Cameroun borders. In Lagos, two survey sites were selected. These were Ajegunle, a lower class high population density area, and Lagos Island, the central business district with middle class residential neighbourhoods. In all, out of a sample population of 597, 397 questionnaires were administered in Lagos. While 199 questionnaires were administered in Ajegunle, 198 were administered in Lagos Island, 200 questionnaires in Kukawa with 50 questionnaires each administered in Cross Kauwa, Baga, Doron Baga and Kukawa. Unlike the Ghanaian survey, the rationale for selecting our Nigerian survey locations was based on maximising social,

\footnotetext{
${ }^{1}$ We would like to thank Centro Militare di Studi Strategici (CeMISS), Italian Ministry of Defence, Rome, for their generous funding of the survey research in both Ghana and Nigeria.

${ }^{2}$ A shorter version of this paper will appear in Stewart (Forthcoming).

${ }^{3}$ The Ghanaian perceptions survey was conducted in July 2005, while the Nigerian one took place in a four-week period in August and September 2005.
} 
political, geographic and economic contrasts. The main reason we were unable to design a sampling strategy similar to the Ghanaian one was the lack of census data on the ethnic composition of Nigerian cities. However, as will be shown in Section 3, the three survey locations in Nigeria (i.e. Ajegunle, Lagos Island and Kukawa) also differed significantly with regard to their ethnic composition. As in the Ghanaian case, we are therefore able to explore whether the ethnic heterogeneity of people's place of living affected their perceptions of the impact of ethnicity and religion in society. As in the Ghanaian case, respondents in the Nigerian survey had to be at least eighteen years old. ${ }^{4}$

The paper proceeds as follows: the next section provides a brief overview of the 'objective' socioeconomic and political horizontal inequalities in both Ghana and Nigeria. Not only it is important to understand the context in which the two surveys were conducted, but it will also be interesting to compare these 'objective' inequalities with respondents' perceptions of the prevailing horizontal inequalities. The third section discusses the ethnic and religious composition of the survey samples in both Ghana and Nigeria. Section 4 analyzes the data on the salience of different identities. Section 5 explores the perceived impact of ethnicity and religion on access to different public amenities and services. Section 6 focuses on the perceived horizontal inequalities in the political-administrative sphere. Section 7 discusses respondents' perceptions of government favouritism and discrimination. The final section draws some conclusions.

\section{2. 'Objective' socioeconomic and political inequalities in Ghana and Nigeria}

Both Ghana and Nigeria are ethnically diverse. While there are 60 different ethnic groups in Ghana, Nigeria is even more fragmented with 374 ethnic groups (see Otite, 1990). In Ghana, the four main ethno-linguistic groups, which together constitute 86 per cent of the population, are the Akan (49.1 per cent), Ewe (12.7 per cent), GaDangme (8.0 per cent) and Mole-Dagbani (16.5 per cent). ${ }^{5}$ The Mole-Dagbani is the main ethnic group in the northern regions and most of them are religiously Muslim. In Nigeria, the three most populous ethnic groups (based on the 1963 Census) are the Hausa-Fulani, Igbo and Yoruba respectively indigenous to the North, East and West of the country. Precise figures of the size of these ethnic groups are unavailable because of the omission of ethnicity in population censuses. There is an important overlap between ethnicity and religion in Nigeria: the Hausa/Fulani and Kanuri are predominantly Muslims, the Igbo and Southern minorities predominantly Christians, and the Yoruba and Northern minorities have an almost equal number of adherents of both religions.

The most marked socioeconomic inequalities in both Ghana and Nigeria relate to the sharp developmental divide between their northern and southern regions, and consequently, due to both countries' ethno-religious demographies, between their northern and southern ethnic groups as well as between Muslims and Christians. The origins of these socio-economic inequalities are diverse and relate to such factors as ecological and climatic differences, the differential impact of colonial policies and post-colonial economic development policies as well as cultural differences between

\footnotetext{
${ }^{4}$ A more extensive discussion of the survey methodology and selection strategy in both Ghana and Nigeria is provided in: Guichaoua, et al. (2006). This report is available upon request from the authors.

${ }^{5}$ The ethnic categorization discussed here is based on the classification used by the Ghana Statistical Service (see, for example, 2000 Ghana Population and Housing Census).
} 
groups (for instance with regard to their receptivity to Western education). The socioeconomic north-south disparities are illustrated in Tables 1 and 2.

Table 1: Various socioeconomic indicators across Ghana's regions, 1997-1999 (percentages)

\begin{tabular}{l|lllll}
\hline & $\begin{array}{l}\text { Incidence of } \\
\text { Poverty }\end{array}$ & $\begin{array}{l}\text { Literacy } \\
(\% \text { literate })^{2}\end{array}$ & $\begin{array}{l}\text { Access to } \\
\text { Electricity }^{2}\end{array}$ & $\begin{array}{l}\text { Access to health } \\
\text { services }^{3}\end{array}$ & $\begin{array}{l}\text { Primary } \\
\text { enrolment }^{3}\end{array}$ \\
\hline Western & 1999 & 1998 & 1998 & 1997 & 1997 \\
Central & 27 & 54 & 37.8 & 28 & 75 \\
Greater Accra & 48 & 55 & 48.3 & 36 & 72 \\
Volta & 38 & 76 & 86.3 & 78 & 70 \\
Eastern & 44 & 58 & 21.4 & 42 & 70 \\
Ashanti & 28 & 66 & 45.2 & 33 & 78 \\
Brong Ahafo & 36 & 64 & 50.4 & 43 & 72 \\
Northern & 69 & 53 & 23.3 & 32 & 72 \\
Upper West & 84 & 13 & 17.5 & 18 & 40 \\
Upper East & 88 & 20 & 7.1 & 8 & 45 \\
National & 40 & 20 & 16.7 & 20 & 36 \\
\hline
\end{tabular}

1) Data drawn from Songsore (2003).

2) Based on data from the 1993 and 1998 Demographic and Health Surveys.

3) Data drawn from the 1997 Ghana Core Welfare Indicators Survey.

Source: Langer (2007: 10)

Table 2: Various socioeconomic indicators across Nigeria's zones in 1995/96 (percentages) $^{\mathrm{a}}$

\begin{tabular}{l|llllll} 
& $\begin{array}{l}\text { Households } \\
\text { without } \\
\text { electricity }\end{array}$ & $\begin{array}{l}\text { Children 6-11 } \\
\text { yrs in school }\end{array}$ & $\begin{array}{l}\text { Children 12 } \\
\text { in school }\end{array}$ & $\begin{array}{l}\text { Literate } \\
\text { adults, 15+ }+\end{array}$ & $\begin{array}{l}\text { Pregnant } \\
\text { women using } \\
\text { clinics }\end{array}$ & $\begin{array}{l}\text { New born } \\
\text { children NOT } \\
\text { immunised }\end{array}$ \\
\hline Northwest & 79.8 & 34.2 & 35.2 & 20.7 & 25.3 & 65.9 \\
Northeast & 78.3 & 42.3 & 47.6 & 25 & 39.4 & 60.7 \\
Northcentral & 61.2 & 69.8 & 73.7 & 44.7 & 66.8 & 54 \\
Southwest & 30.4 & 94.6 & 88.9 & 68.9 & 74.7 & 29.1 \\
Southeast & 47.7 & 88.3 & 89.6 & 75.8 & 84.8 & 29 \\
Southsouth & 55.7 & 90.9 & 87.6 & 77.2 & 60.7 & 56.9 \\
\hline
\end{tabular}

a) Adapted from Federal Office of Statistics (FOS), 1995/96, General Household Survey 1995/96 National report.

Source: Mustapha (2005: 8).

Table 1 shows that Ghana's three northern regions (Upper East, Upper West and Northern) not only lagged severely behind on all the depicted socioeconomic indicators compared to the Greater Accra region, which is where Ghana's capital, Accra, is located, but also compared to the other regions in the south. When the current New Patriotic Party (NPP) government, led by President John Agyekum Kufuor, came to power in January 2001, it acknowledged the problematic nature of the socioeconomic north-south disparities and subsequently increased public spending on health, social infrastructure and education in the northern regions. Moreover, the funds that were freed up as part of the Highly Indebted Poor Country 
(HIPC) were earmarked to benefit the northern regions disproportionately (Shepherd, et al. 2005). However, despite the increased public expenditure in the north over the last couple of years, the socioeconomic north-south divide has not been reduced much (if at all) and thus remains very severe. As we did not have a survey site in the northern regions in Ghana, a comparison between the 'objective' socioeconomic inequalities and northern people's perceptions thereof can only be done by assuming that the views of the respondents with northern origins who live in the south are a good approximation of their northern counterparts. As will be shown below, only in the Kumasi sample were there sufficient respondents with northern origins (almost exclusively Mole-Dagbanis) to make reliable inferences.

Table 3: Ethnoregional composition of various Ghanaian governments, 1993-2005 (percentages unless otherwise stated)

\begin{tabular}{|c|c|c|c|c|c|c|c|c|c|}
\hline \multirow{3}{*}{$\begin{array}{l}\text { Ethnic group } \\
\text { Akan }\end{array}$} & \multicolumn{9}{|c|}{ Government Ministers } \\
\hline & \multicolumn{2}{|c|}{1993} & \multicolumn{2}{|c|}{1997} & \multicolumn{2}{|l|}{2002} & \multicolumn{2}{|c|}{2005} & \multirow{2}{*}{$\begin{array}{l}\text { Population }^{b} \\
49.1\end{array}$} \\
\hline & 19 & 51.4 & 14 & 51.9 & 27 & 65.9 & 26 & 66.7 & \\
\hline Ewe & 4 & 10.8 & 3 & 11.1 & 3 & 7.3 & 3 & 7.7 & 12.7 \\
\hline Ga-Dangmes & 3 & 8.1 & 3 & 11.1 & 4 & 9.8 & 4 & 10.3 & 8.0 \\
\hline $\begin{array}{l}\text { Northern } \\
\text { groups }^{\mathrm{a}}\end{array}$ & 11 & 29.7 & 7 & 25.9 & 7 & 17.1 & 6 & 15.4 & 24.4 \\
\hline \multirow[t]{2}{*}{$\begin{array}{l}\text { Total number of } \\
\text { positions }\end{array}$} & 37 & & 27 & & 41 & & 39 & & 94.2 \\
\hline & \multicolumn{9}{|c|}{ Government including Deputy-Ministers } \\
\hline Ethnic group & 1993 & & 1997 & & 2002 & & 2005 & & Population \\
\hline Akan & 36 & 48.0 & 36 & 46.2 & 40 & 56.3 & 60 & 69.0 & 49.1 \\
\hline Ewe & 10 & 13.3 & 10 & 12.8 & 4 & 5.6 & 3 & 3.4 & 12.7 \\
\hline Ga-Dangmes & 7 & 9.3 & 8 & 10.3 & 8 & 11.3 & 9 & 10.3 & 8.0 \\
\hline $\begin{array}{l}\text { Northern ethnic } \\
\text { groups }\end{array}$ & 22 & 29.3 & 24 & 30.8 & 19 & 26.8 & 15 & 17.2 & 24.4 \\
\hline $\begin{array}{l}\text { Total number of } \\
\text { positions }\end{array}$ & 75 & & 78 & & 71 & & 87 & & 94.2 \\
\hline
\end{tabular}

a) Northern ethnic groups consist of the Mole-Dagbani, Gurma and Grusi ethnic groups.

b) 2000 Ghana Population and Housing Census.

Source: Langer (2006).

In Nigeria a similar picture emerges. The two northern most zones, Northwest and Northeast, are the least developed in socioeconomic terms (see Table 2). And while the third northern zone, Northcentral, was doing considerably better in socioeconomic terms, it is still significantly less developed than the relatively most developed zones, Southwest and Southeast. It is important to recall that Kukawa, our northern survey location, is located in the Northeastern zone. The main reason why Northcentral is doing somewhat better in socioeconomic terms than the other two northern zones is because Nigeria's capital, Abuja, is located in this zone. Another interesting finding that emerges from Table 2 is that the Southsouth zone performs almost equally badly as the Northcentral zone when it comes to access to electricity, immunisation of new-born babies and the proportion of pregnant women who have access to health clinics.

The socioeconomic 'backwardness' of the northern regions in Ghana and Nigeria was however not complemented by the exclusion of the northerners from political power. Indeed, in both countries, northern political elites have generally been included in various national/federal governments in the post-independence period 
(see Langer 2007 for a more detailed discussion of the ethno-regional composition of Ghana's post-independence national governments; for Nigeria see Mustapha 2005). Table 3, showing the ethnoregional composition of four Ghanaian governments, illustrates this for Ghana's Fourth Republic which was established in January 1993. The table shows that the Rawlings governments of April 1993 and October 1997 were exceptionally well balanced in ethnic terms. While the Akan were the largest ethnic group in both these governments (occupying around 51-52 per cent of all ministerial positions), the northern ethnic groups were also well represented. Indeed, they were actually slightly over-represented in relation to their demographic size in Ghana's population as a whole. Under Kufuor, the ethnic composition of the government became somewhat less balanced. For instance, in Kufuor's February 2005 government about 69 per cent of the ministers and deputy-ministers were Akan, even though they only constitute about 50 per cent of Ghana's population. Furthermore, Kufuor and his New Patriotic Party's (NPP) poor showing in the Volta region during both the 2000 and 2004 elections was translated into a marginalisation of the Ewes in his governments. While the northern ethnic groups have become noticeably under-represented among government ministers in relation to their demographic size in Ghana's population as a whole, Kufuor appears to have compensated this underrepresentation by appointing a more than proportionate number of deputy-ministers from among the northern ethnic groups. Furthermore, the fact that the position of Vice President, the second most important position in Ghana's 1992 Constitution, has been occupied by a northerner, Alhaji Aliu Mahama, since January 2001 has also contributed to reducing the political salience of the northern under-representation among government ministers (Langer 2007).

Due to their demographic significance in Nigeria, the 'northerners' were generally very well represented in various federal governments since independence in 1960. Table 4, showing the zonal composition of four Nigerian governments in the period 1985-2004, illustrates this. It is noteworthy that in all four governments, the 'northerners' were moderately overrepresented in relation to their demographic size in Nigeria's population as a whole. Indeed, it is sometimes argued that the northerners have actually dominated political power at the federal level because ten of the thirteen Nigerian heads of state had northern origins. ${ }^{6}$

Table 4: Zonal composition of various Nigerian cabinets, 1983-2004 (percentages unless otherwise stated)

\begin{tabular}{l|llllllllllll}
\hline Zone & 1985 & & 1986 & & 1990 & & 1993 & & 2004 & Population \\
\hline Northwest & 6 & 27.3 & 5 & 22.7 & 6 & 33.3 & 5 & 22.7 & 7 & 21.2 & 25.8 \\
Northeast & 2 & 9.1 & 2 & 9.1 & 3 & 16.7 & 3 & 13.6 & 5 & 15.1 & 13.4 \\
Northcentral & 4 & 18.2 & 5 & 22.7 & 2 & 11.1 & 4 & 18.2 & 6 & 18.2 & 13.6 \\
Southwest & 5 & 22.7 & 5 & 22.7 & 3 & 16.7 & 4 & 18.2 & 5 & 15.1 & 19.6 \\
Southeast & 2 & 9.1 & 2 & 9.1 & 3 & 16.7 & 2 & 9.1 & 4 & 12.1 & 12.1 \\
$\begin{array}{l}\text { Southsouth } \\
\begin{array}{l}\text { Total number } \\
\text { of positions }\end{array}\end{array}$ & 3 & 13.6 & 3 & 13.6 & 1 & 5.5 & 4 & 18.2 & 6 & 18.2 & 15.1 \\
\hline
\end{tabular}

Source: Langer et al. (2007: 32) and Mustapha (2005: 7).

\footnotetext{
${ }^{6}$ This includes the military leaders who seized power by a non-constitutional means.
} 


\section{Ethnic and religious composition of the survey samples}

Given the centrality of ethnicity and religion to our analysis, it is apposite briefly to discuss the ethnic and religious composition of our survey samples. Table 5 and Table 6 respectively show the ethnic composition of the Ghanaian and Nigerian survey sites, according to self-identification in the surveys, that is, the preferred identification of each respondent. In the Ghanaian case, Accra was as expected the most ethnically heterogeneous city surveyed. The largest ethnic group in the Accra sample were the Ga-Dangmes. This is mainly because they are indigenous to Accra and consequently constitute a significant proportion of the population. The second largest ethnic group in the Accra sample were the Akans who are the largest ethnic group in Ghana. The Akan constitute about 50 per cent of the Ghanaian population. It is however important to emphasize that the Akan group is an amalgamation of around twenty smaller ethnic groups. The most populous sub-Akan groups are the Ashanti (roughly 30 per cent of the Akan) and Fanti (roughly 20 per cent of the Akan). The third largest group in the Accra sample were the Ewe with 13.4 per cent. The Ewe originate from the Volta Region in the eastern part of the country, where they constitute a large majority of the population. The fourth largest group in the Accra sample were the Mole-Dagbani who make up only about 2 per cent of the respondents. Although the Mole-Dagbani are the second largest ethnic group in Ghana, with about 16.5 per cent of the population, their relatively small representation in the Accra sample is due to the fact that they are indigenous to and predominantly live in the three northern regions (i.e. Upper East, Upper West and Northern regions), as mentioned earlier.

Table 5: Ethnic composition of the Ghanaian survey (percentages)

\begin{tabular}{|l|lllll|}
\hline & Akan & Ewe & Ga-Dangme & Mole-Dagbani & Other \\
\hline Accra & 36.3 & 13.4 & 36.9 & 2.0 & 11.1 \\
Ho & 8.2 & 80.3 & 1.6 & 3.3 & 6.5 \\
Kumasi & 78.4 & 5.4 & 0.4 & 11.2 & 4.6 \\
\hline
\end{tabular}

Table 6: Ethnic composition of the Nigerian survey (percentages)

\begin{tabular}{|l|llllll|}
\hline & Yoruba & Igbo & $\begin{array}{l}\text { Hausa/ } \\
\text { Fulani }\end{array}$ & Kanuri & $\begin{array}{l}\text { Southern } \\
\text { minorities }\end{array}$ & $\begin{array}{l}\text { Northern } \\
\text { minorities }\end{array}$ \\
\hline Ajegunle Lagos & 34.8 & 34.3 & 0.5 & 19.2 & 11.1 & 0.0 \\
Lagos Island & 87.4 & 6.5 & 2.0 & 0.5 & 2.0 & 0.0 \\
Kukawa & 0.5 & 0.0 & 48.5 & 42.5 & 0.0 & 8.5 \\
\hline
\end{tabular}

The second city surveyed was Ho which is the regional capital and largest city of the Volta Region. About 80 per cent of the respondents in the Ho sample were Ewe. The largest minority ethnic group in the Ho sample were the Akan with around 8 per cent of the respondents. The reverse situation occurred in the third city surveyed, which was Kumasi, the regional capital of the Ashanti Region. While the Akan were the dominant ethnic group in the Kumasi sample, constituting about 78 per cent of the respondents, the Ewe constituted a small minority of 5.4 per cent. The largest minority ethnic group in the Kumasi sample were the Mole-Dagbani with 
approximately 11 per cent. Therefore, in accordance with our sampling objectives, $\mathrm{Ho}$ and Kumasi were indeed much more ethnically homogenous than Accra.

Given the high level of ethnic fragmentation in Nigeria, the ethnic identities mentioned in the survey were aggregated on the basis of the major ethno-regional identities in the country, namely: Hausa/Fulani, Kanuri, Northern minorities, Yoruba, Igbo and Southern minorities. As shown in Table 6, the Nigerian survey included respondents who belonged to all six of these ethno-regional groupings. Table 6 also shows that Ajegunle was the ethnically most diverse survey location, while LagosIsland was the ethnically most homogeneous one. Kukawa fell somewhere in between these two 'extremes'; however, its ethnic composition was arguably closer to the ethnically diverse Ajegunle site. In Ajegunle, the Yoruba were the largest ethnic group, although only marginally larger than the Igbo. The Yoruba originate from south-western Nigeria and are therefore demographically dominant in Lagos. This is particularly evident in the Lagos Island sample where they constituted over 87 per cent of the respondents. The Igbo were the second largest ethnic group in the Lagos Island sample with approximately 34 per cent of the respondents. While they originate from south-eastern Nigeria, they have traditionally migrated to other parts of the country for business and employment opportunities. In the Kukawa sample, the Kanuri with about 42.5 per cent and Hausa/Fulani with about 48.5 per cent of the respondents were the two major ethnic groups, while about 8.5 per cent of the respondents belonged to a Northern minority ethnic group. Taking into account Nigeria's ethnic demography, it was unsurprising that virtually all of the Hausa/Fulani and Northern minorities respondents were interviewed in Kukawa, while almost all of the Yoruba, Southern minorities and Igbo respondents were based in Lagos.

Table 7: Religious composition of the Ghanaian survey (percentages)

\begin{tabular}{|l|llllll|}
\hline & Catholic & Protestant & $\begin{array}{l}\text { Pentecostal/ } \\
\text { Charismatic }\end{array}$ & $\begin{array}{l}\text { Other } \\
\text { Christian }\end{array}$ & Islam & $\begin{array}{l}\text { No religion/ } \\
\text { Traditional }\end{array}$ \\
\hline Accra & 8.8 & 24.5 & 46.4 & 8.2 & 9.5 & 2.3 \\
Ho & 16.4 & 36.1 & 36.1 & 4.9 & 1.6 & 3.3 \\
Kumasi & 15.4 & 15.4 & 41.1 & 10.0 & 14.1 & 3.7 \\
\hline
\end{tabular}

Table 8: Religious composition of the Nigerian survey (percentages)

\begin{tabular}{|l|llllll|}
\hline & Catholic & Protestant & $\begin{array}{l}\text { Pentecostal/ } \\
\text { Charismatic }\end{array}$ & $\begin{array}{l}\text { Other } \\
\text { Christian }\end{array}$ & Islam & $\begin{array}{l}\text { No religion/ } \\
\text { Traditional }\end{array}$ \\
\hline Ajegunle Lagos & 21.7 & 6.6 & 36.4 & 15.2 & 15.2 & 5.1 \\
Lagos Island & 8.5 & 10.6 & 12.1 & 6.5 & 60.8 & 1.5 \\
Kukawa & 0.0 & 0.0 & 0.0 & 0.0 & 99.5 & 0.5 \\
\hline
\end{tabular}

Table 7 and Table 8 respectively show the religious composition of the Ghanaian and Nigerian sampled sites. In the Ghanaian survey, the three survey locations were predominantly Christian, reflecting the predominance of the Christians in Ghana's population as a whole: approximately 88 per cent, 94 per cent and 82 per cent of the respondents in Accra, Ho and Kumasi respectively adhered to one of the Christian denominations (i.e. Catholic, Protestant and Pentecostal/Charismatic). Islam was the largest minority religion both in Accra (9.5 per cent) and Kumasi (14.1 per cent). In Ho, however, only 1.6 per cent of the respondents were Muslim which was less than the 3.3 per cent of the respondents who declared themselves as having a traditional religion or no specific religion whatsoever. Although Muslims are a minority in the 
southern regions of Ghana, in two of the three northern regions (i.e. Northern and Upper East regions), Islam is the largest religion. Ghana's religious north-south divide should however not be exaggerated because Christians and Traditionalists together constitute the majority of the population in the three northern regions.

As a result of Nigeria's ethno-religious demography and geography, the Kukawa sample, with a vast majority of Kanuri and Hausa/Fulani respondents, was dominated by Muslims, while, conversely, Christian respondents were by far the largest religious group in the Ajegunle sample (about 80 per cent of the respondents was Christian). In the Lagos Island sample, the largest religious group was the Muslims (about 60 per cent). Christian respondents constituted about 18 per cent of respondents in Lagos Island. The religious composition of the Lagos respondents stems from the cosmopolitan status of Lagos as well as the fact that the Yoruba embraced both Christianity and Islam almost evenly (see Laitin, 1986).

\section{The salience of different identities}

Having considered the ethnic and religious composition of the sampled population, it is pertinent to explore the significance of these identities. In other words, does the ethnic and religious composition of a place matter to people? Are there other identities or markers that people consider more important than ethnicity and religion? In this respect, respondents were asked to choose three identities (from among a list of nine possible categories) which they considered most important for the way they thought about themselves. Figures 1 and 2 show the proportion of respondents in the different survey locations in Ghana and Nigeria who mentioned a particular aspect of identity as one of their three most important identities. The first set of bars in Figure 1 indicate that 72 per cent, 73 per cent and 80 per cent of the respondents in Accra, Ho and Kumasi respectively considered religion to be one of their three most important identities. Overall, Ghanaian respondents had very similar views regarding the relative importance of different identities, regardless of survey location and therefore the extent of ethnic heterogeneity of their place of living. Only with regard to the proportion of respondents who mentioned nationality was there a significant difference in the three survey locations.

Figure 1: Three most important forms of self-identification in Ghana according to survey location

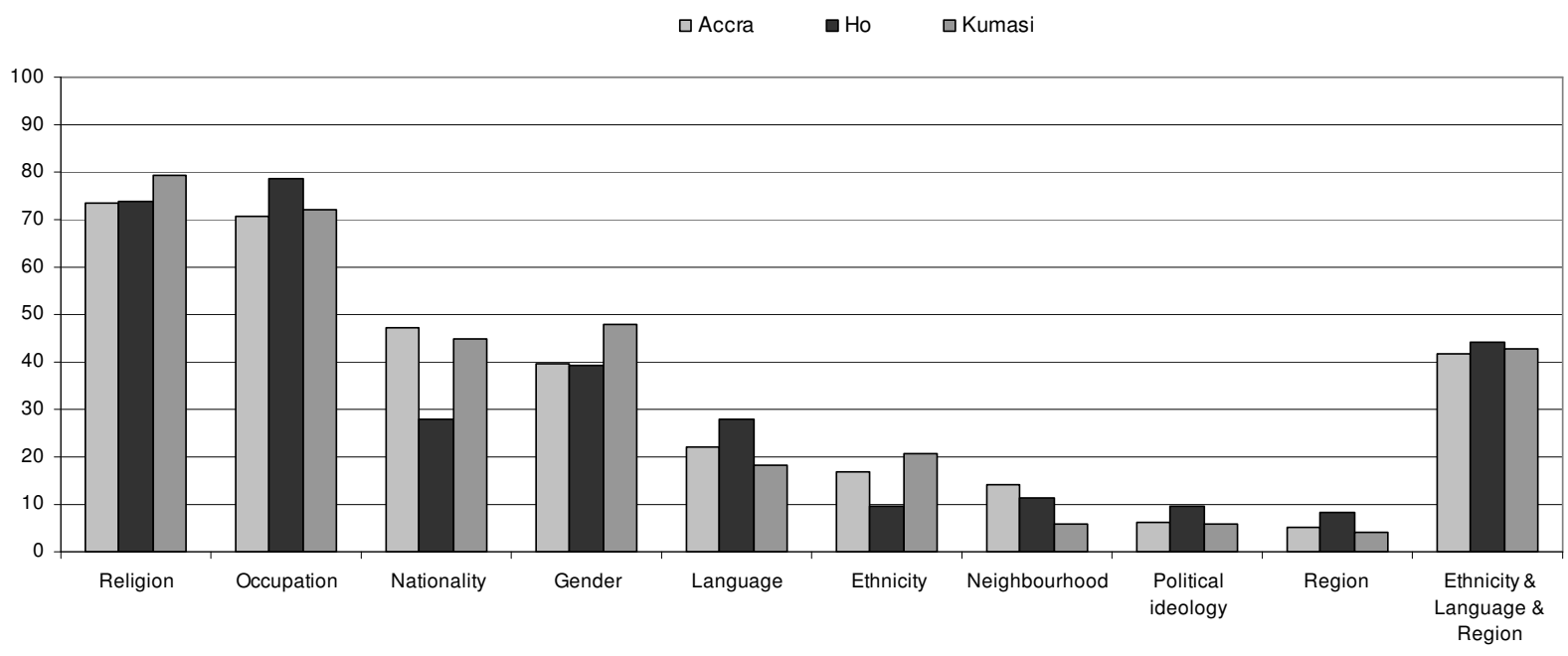


Figure 2: Three most important forms of self-identification in Nigeria according to survey location

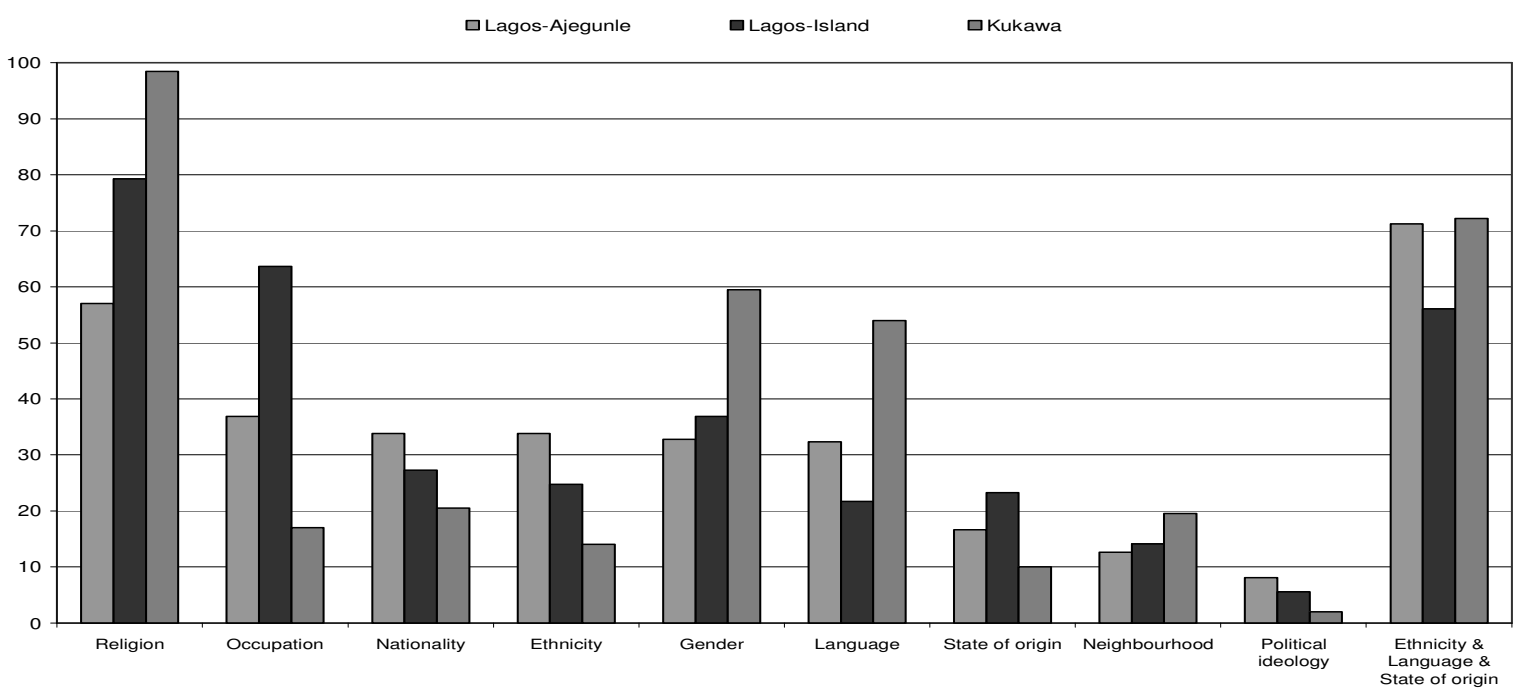

As shown in Figure 1, over 70 per cent of the respondents in Accra, Ho and Kumasi considered both religion and occupation to be among their three most important aspects of identity. In all three survey locations, a noticeably smaller proportion of respondents (varying between 28-48 per cent) considered nationality or gender as one of their three most important identities. Interestingly, only a minority of less than 20 per cent of the respondents mentioned ethnicity in this respect. However, the latter finding might be due to the fact that ethnicity, language and region of origin are sometimes used interchangeably in the Ghanaian context. Ethnicity and language are particularly closely related as many ethnic groups are named after the language they speak (for example, Ewe and Akan). Consequently, respondents who mentioned any one of these three aspects might actually have been referring to the other two. In order to get an indication of the salience of this broadly defined 'ethnic' identity, we aggregated respondents who mentioned either ethnicity or language or region of origin (see the set of bars furthest to the right in Figure 1). ${ }^{7}$ This reveals that about 40 per cent of the respondents considered this ethno-regional/linguistic identity as one of their three most important identities. While this is comparable to the proportion of respondents who considered nationality and gender to be among their three most important identities, it was considerably lower than the proportion who mentioned religion or occupation.

In contrast to Ghana, there were significant variations across the three survey locations in Nigeria with regard to the salience of the different identities. These differences not only related to the proportions of respondents who considered a particular identity as one of their three most important identities, but also included a different ranking of the different identities in the three survey locations. To illustrate the first point, consider the differences in the proportion of respondents who mentioned religion as one of their three most important identities: while 56 per cent of the respondents in Ajegunle considered religion as one of their three most important identities, in Lagos Island, this was 79 per cent, and in all four sampled areas in Kukawa nearly every respondent mentioned religion (see Figure 2). With

\footnotetext{
${ }^{7}$ Respondents who mentioned more than one of these identity aspects (i.e. ethnicity, language and region of origin) among their three most important ones, were only counted once.
} 
regard to the ranking differences, it is noteworthy that while the two most important identities in Ajegunle and Lagos Island were the same (i.e. religion and occupation), the third one differed in both locations (i.e. nationality in Ajegunle and gender in Lagos Island). Compared to the two survey locations in Lagos, Kukawa showed a very different ranking. In particular, the three most important identities in Kukawa turned out to be (in descending order of importance) religion, gender and language. Thus, while religion once more emerged as the most important identity, the second and third most important identities in Kukawa differed from the survey locations in Lagos. A possible reason for the relative importance of occupation in Lagos (particularly in Lagos-Island), but not in Kukawa, and language in Kukawa but not in Lagos, might be the different nature of these survey locations. While Kukawa is still largely a traditional society, Lagos is a modern metropolis.

Like in Ghana, ethnicity as such did not emerge as a particularly important aspect for the way Nigerian respondents perceived themselves. Yet, in Nigeria, even more so than in Ghana, ethnicity, language and state of origin are often used interchangeably and tend to refer to a similar kind of identity. Figure 2 shows that when this broader usage of ethnicity is considered through the aggregation of the three aspects, more than 70 per cent of the respondents in Ajegunle and all Kukawa sites considered ethnicity as one of their three most important identities. In Lagos Island, the ethnically most homogenous survey location, the proportion of respondents who mentioned this broadly defined ethnic identity was somewhat lower, but still around 56 per cent of the respondents mentioned it. Therefore, Nigerian respondents (regardless of the ethnic heterogeneity of their place of living) appeared to attach considerably more importance to ethnic background than the Ghanaian respondents, suggesting that ethnicity is more salient in Nigerian society.

This is further substantiated by the finding that ethnicity was also relatively more important (i.e. in relation to other identities) in Nigeria than in Ghana. While in the Ghanaian survey, the proportion of respondents who mentioned ethnicity as defined in broad terms was comparable to those who mentioned nationality and gender this was, nonetheless, considerably smaller than the proportion who considered religion and occupation to be among their three most important identities (see Figure 1). In the Nigerian survey, in contrast, ethnicity (again broadly defined) emerged as the second and third most important identity in Kukawa and Lagos Island respectively, and the most important identity in Ajegunle (see Figure 2). However, while the respondents in both countries differed substantially regarding the relative importance they attached to their ethno-regional and linguistic origins and backgrounds, they had very similar perceptions with regard to religion. In all locations in Ghana and Nigeria, respondents considered religion as one of their two most important identities.

\section{The perceived impact of ethnicity and religion in the public sphere}

In order to assess the perceived impact of ethnicity and religion in the public sphere in Ghana and Nigeria, the questionnaire asked respondents whether they thought ethnic or religious background affected someone's chances of getting government jobs, government contracts, public housing, pre-university education and university education. The answers are shown in Tables 9 and 10. In the Ghanaian survey, the proportion of respondents who thought that ethnic background affected someone's chances of getting government jobs, government contracts and public housing was considerably larger than the proportion of respondents who perceived this to be the case with regard to getting educational opportunities. But there were some significant differences across locations. The proportion of respondents in Ho who perceived that 
ethnic background affected the chance of getting government jobs, government contracts, public housing and educational opportunities was consistently the largest of the three survey locations, while the proportion of respondents in Kumasi who perceived this to be the case was consistently the lowest and replies from Accra were between those from $\mathrm{Ho}$ and Kumasi. The respondents in $\mathrm{Ho}$ and Kumasi differed most when it came to the perceived impact of ethnicity on gaining access to government employment and contracts. In particular, while about 25 per cent of the respondents in Kumasi thought that ethnicity affected someone's chances of getting government employment and contracts, between 50-54 per cent of the respondents in Ho had this perception.

Table 9: The proportion of Ghanaian respondents according to survey location who thought that ethnicity affected someone's chances of getting ...

\begin{tabular}{|l|lllll|}
\hline & $\begin{array}{l}\text { Government } \\
\text { jobs }\end{array}$ & $\begin{array}{l}\text { Government } \\
\text { contracts }\end{array}$ & Public housing & $\begin{array}{l}\text { Pre-university } \\
\text { education }\end{array}$ & $\begin{array}{l}\text { University } \\
\text { education }\end{array}$ \\
\hline Accra & 39.5 & 38.6 & 39.5 & 18.6 & 16.0 \\
Ho & 54.1 & 50.8 & 42.6 & 26.2 & 27.9 \\
Kumasi & 24.9 & 24.9 & 35.7 & 11.2 & 9.1 \\
\hline
\end{tabular}

Table 10: The proportion of Nigerian respondents according to survey location who thought that ethnicity affected someone's chances of getting ...

\begin{tabular}{|l|lllll|}
\hline & $\begin{array}{l}\text { Government } \\
\text { jobs }\end{array}$ & $\begin{array}{l}\text { Government } \\
\text { contracts }\end{array}$ & Public housing & $\begin{array}{l}\text { Pre-university } \\
\text { education }\end{array}$ & $\begin{array}{l}\text { University } \\
\text { education }\end{array}$ \\
\hline Ajegunle Lagos & 58.6 & 60.1 & 42.4 & 37.4 & 46.0 \\
Lagos Island & 57.2 & 56.7 & 28.9 & 44.8 & 43.3 \\
Kukawa & 35.5 & 32.0 & 30.5 & 22.0 & 22.0 \\
\hline
\end{tabular}

Kumasi is predominantly inhabited by Akan, while $\mathrm{Ho}$ is dominated by Ewe. Therefore, the differences between Ho and Kumasi also tell us something about the differences in perceptions between these two ethnic groups. Interestingly, the Akan and Ewe respondents in the Accra sample also had different perceptions on the same issue (i.e. of chances of getting government jobs and contracts): while 38 per cent and 34 per cent of the Akan respondents in the Accra sample considered ethnicity to affect a person's chances of getting government jobs and contracts respectively, for the Ewe respondents, this was 44 per cent and 46 per cent. The proportion of Ga-Dangmes who perceived ethnicity to affect someone's chances of getting government employment and contracts was somewhere in between that of the Akan and Ewe respondents. Although the Akan and Ewe respondents in Accra had different views regarding the impact of ethnicity in the public sphere, they appeared to be less at odds than their ethnic counterparts in Ho and Kumasi. The views of the Mole-Dagbani respondents in the Kumasi sample, which we take here as an approximation of the views of the 'northerners', also proved interesting. Not only were they less concerned about the impact of ethnicity on getting access to government jobs, contracts and public housing than the Akan respondents in Kumasi (only about 22 per cent of the Mole-Dagbani respondents thought that ethnic background affected someone's chances in this respect), but also a considerably smaller proportion of them (in particular 3.7 per cent or one out of 27 respondents) thought that ethnic background affected someone's chances of getting educational opportunities. This is all the more interesting if one considers the severe educational inequalities between the northern and southern regions (see Table 1).

Differences in perceptions between the Akan and Ewe regarding access to government jobs and contracts are likely to be influenced and to some extent 
provoked by the fact that the current NPP government, led by President John Agyekum Kufuor (an Ashanti from the Ashanti Region where he has royal ancestry), is widely regarded as a pro-Ashanti/Akan government. Since its inception in 1992 the NPP has been perceived by a majority of Ghanaians as a largely Akan-based party, despite the fact that NPP's hierarchy has continued to be multiethnic (Gyimah-Boadi and Asante 2006). A likely reason for the persistence of this perception under Kufuor is the relative over-presentation of the Akan in government since he came to power in January 2001 (see Table 3).

The proportion of Nigerian respondents who perceived ethnic background to affect a person's chances of getting access to the different public amenities and services was considerably larger (particularly in Lagos) than in the Ghanaian survey (see Tables 9 and 10). And while, like in Ghana, the proportion of respondents who thought that ethnic background affected someone's chances of getting educational opportunities was noticeably smaller than in relation to government jobs and contracts, in the two survey locations in Lagos between 37-46 per cent of the respondents nonetheless perceived ethnicity to affect a person's chances of getting pre-university and university education. Interestingly, in Kukawa, the location with the lowest enrolment and literacy rates, only about 22 per cent of the respondents thought that a person's chances of getting pre-university and university education were affected by ethnic background. Arguably, a major reason why considerably more respondents in the Nigerian survey perceived ethnic background to affect the chance of getting access to the different public amenities and services is the presence of 'affirmative action' programmes, such as the federal character principle with regard to employment in state institutions and the use of quotas in university admission.

Like in the Ghanaian survey, Table 10 also shows that there were significant differences between the three survey locations in Nigeria. Taking into account the ethnic composition of the locations, it is clear that the southern (i.e. Yoruba, Igbo and Southern minorities) and northern ethnic groups (i.e. Hausa-Fulani, Kanuri and Northern minorities) had very different perceptions regarding the impact of ethnicity in the public sphere. It is clear that the southern ethnic groups (who were virtually all interviewed in Lagos) were much more concerned about the impact of ethnicity on getting access to the different public amenities and services than the northern ethnic groups (who were predominantly interviewed in Kukawa). Moreover, from a comparative perspective, it is striking to note that both in the Ghanaian and Nigerian surveys, the ethno-regional groups (i.e. the Ewe in Ghana and the southern ethnic groups in Nigeria) who feel either presently and/or historically excluded from political power, were the ones most concerned about the impact of ethnicity in the public sphere.

Increased levels of education are sometimes argued to be likely to reduce people's attachments to ethnic background loyalty. For instance, those who adopt a modernization perspective towards ethnicity and national integration have posited that the attainment of higher levels of education would reduce ethnic loyalties (see, for example, Deutsch, 1961). In order to explore the relevance and validity of the modernization thesis in the Ghanaian and Nigerian contexts, we cross-tabulate respondents' level of education and the perceptions of the importance of ethnic background on access to the different public goods for the survey locations in Ghana and Nigeria as shown in Tables 11 and 12. 
Table 11: The proportion of Ghanaian respondents according to educational background and survey location who thought that ethnicity affected someone's chances of getting ...

\begin{tabular}{|c|c|c|c|c|c|}
\hline & $\begin{array}{l}\text { Government } \\
\text { jobs }\end{array}$ & $\begin{array}{l}\text { Government } \\
\text { contracts }\end{array}$ & Public housing & $\begin{array}{l}\text { Pre-university } \\
\text { education }\end{array}$ & $\begin{array}{l}\text { University } \\
\text { education }\end{array}$ \\
\hline \multicolumn{6}{|l|}{ Accra } \\
\hline Primary completed & 28.8 & 30.8 & 34.6 & 13.5 & 13.5 \\
\hline Secondary completed & 39.5 & 38.5 & 41.5 & 20.0 & 16.5 \\
\hline $\begin{array}{l}\text { Post-secondary } \\
\text { qualifications and higher } \\
\text { Ho }\end{array}$ & 50.0 & 46.3 & 37.0 & 18.5 & 16.7 \\
\hline Primary completed & 40.0 & 20.0 & 20.0 & 20.0 & 20.0 \\
\hline Secondary completed & 45.2 & 41.9 & 29.0 & 25.8 & 25.8 \\
\hline $\begin{array}{l}\text { Post-secondary } \\
\text { qualifications and higher } \\
\text { Kumasi }\end{array}$ & 68.0 & 68.0 & 64.0 & 28.0 & 32.0 \\
\hline Primary completed & 11.1 & 11.1 & 27.8 & 7.4 & 5.6 \\
\hline Secondary completed & 26.3 & 26.3 & 37.5 & 11.3 & 8.8 \\
\hline $\begin{array}{l}\text { Post-secondary } \\
\text { qualifications and higher }\end{array}$ & 46.2 & 46.2 & 42.3 & 19.2 & 19.2 \\
\hline
\end{tabular}

Table 12: The proportion of Nigerian respondents according to educational background and survey location who thought that ethnicity affected someone's chances of getting ...

\begin{tabular}{|c|c|c|c|c|c|}
\hline & $\begin{array}{l}\text { Government } \\
\text { jobs }\end{array}$ & $\begin{array}{l}\text { Government } \\
\text { contracts }\end{array}$ & Public housing & $\begin{array}{l}\text { Pre-university } \\
\text { education }\end{array}$ & $\begin{array}{l}\text { University } \\
\text { education }\end{array}$ \\
\hline \multicolumn{6}{|l|}{ Ajegunle Lagos } \\
\hline Primary completed & 53.3 & 53.3 & 46.7 & 43.3 & 46.7 \\
\hline Secondary completed & 52.6 & 52.6 & 40.2 & 33.0 & 42.3 \\
\hline $\begin{array}{l}\text { Post-secondary } \\
\text { qualifications and higher } \\
\text { Lagos Island }\end{array}$ & 68.2 & 72.7 & 42.4 & 37.9 & 48.5 \\
\hline Primary completed & 48.1 & 37.0 & 7.4 & 29.6 & 33.3 \\
\hline Secondary completed & 53.1 & 59.2 & 29.6 & 43.9 & 40.8 \\
\hline $\begin{array}{l}\text { Post-secondary } \\
\text { qualifications and higher } \\
\text { Kukawa }\end{array}$ & 67.7 & 63.1 & 38.5 & 55.4 & 53.8 \\
\hline Primary completed & 35.5 & 32.3 & 31.0 & 22.6 & 22.6 \\
\hline Secondary completed & 36.8 & 36.8 & 36.8 & 26.3 & 26.3 \\
\hline $\begin{array}{l}\text { Post-secondary } \\
\text { qualifications and higher }\end{array}$ & 43.8 & 37.5 & 31.3 & 25.0 & 25.0 \\
\hline
\end{tabular}

There is a consistent pattern discernible in both the Ghanaian and Nigerian surveys with regard to the perceived impact of ethnic background on access to government jobs and contracts. We find that the higher the level of education of a respondent, the more likely he/she is to think that ethnic background affected someone's chances of accessing public goods. This pattern was consistent across all survey locations and levels of education, except for the second highest educational group in the Ajegunle site. A possible reason why highly educated people are more likely to think that ethnicity affects someone's chances of getting government employment and contracts is that educated people, who largely constitute the technocracy, bureaucracy and business class are more directly engaged in the competition for these public goods. Moreover, while the respondents in the Nigerian survey generally perceived ethnicity to be more of a factor in accessing public goods than respondents 
with a similar level of education in the Ghanaian survey, it is striking to note that the highest educated respondents in Ho, who were almost exclusively Ewe, were as concerned as those in the Nigerian surveys about the impact of ethnicity on access to government jobs and contracts.

In order to analyze the perceived impact of religion in the public sphere, Tables 13 and 14, show the proportion of respondents who thought that religion affected someone's chances of accessing the different public goods in Ghana and Nigeria. It is of significance that religion was considered to be a less influential factor in getting access to the different public amenities and services than ethnicity in all survey locations in both Ghana and Nigeria. This is particularly noteworthy in the Nigerian context where there is often an overlap between religious and ethnic identities. In the Ghanaian survey, only Kumasi and Accra had a significant number of Muslim respondents to allow for a direct comparison between Muslims and Christians. Two important findings emerged in this respect. First, both the Muslim and Christian respondents in Kumasi were significantly less concerned about the impact of religion in the public sphere than their religious counterparts in Accra. This was unsurprising given that the proportion of respondents in Kumasi who perceived religion to affect someone's chances of getting the different public amenities and services was overall significantly smaller than in Accra (see Table 13). Second, while the proportion of Muslim respondents in both Accra and Kumasi who perceived religion to affect someone's chances of getting government jobs, government contracts and public housing was consistently larger than that of the Christian respondents, with regard to getting access to pre-university and university education, in contrast, the proportion of Christian respondents was larger than that of the Muslim respondents.

The analysis of how Muslims and Christians in the survey locations in Nigeria perceived the impact of religion also proved interesting. It is important to remember that in the Kukawa sample virtually every respondent was Muslim; in the Lagos Island sample, Muslims constituted the majority with around 60 per cent of the respondents; and, in the Ajegunle sample, while Christians formed the majority of the respondents, Muslims still constituted around 15 per cent of the respondents (see Table 8). An important finding with regard to the Nigerian survey was that the smaller the proportion of Muslims in the population of a survey location, the larger the proportion of Muslim respondents who perceived religion to affect a person's chances of getting the different public amenities and services. The following figures illustrate this: 24 per cent, 31 per cent and 38 per cent of the Muslim respondents in Kukawa, Ajegunle and Lagos Island respectively thought that religion affected someone's chances of getting government employment. Significantly, this pattern not only emerged with regard to government employment, but was also found with regard to government contracts, public housing and educational opportunities. Only in the cases of Muslim respondents in Kukawa and Lagos Island -who thought that religion affected a person's chances of getting public housing- was the pattern not consistent. 
Table 13: The proportion of Ghanaian respondents according to survey location who thought that religion affected someone's chances of getting ...

\begin{tabular}{|l|lllll|}
\hline & Government jobs & $\begin{array}{l}\text { Government } \\
\text { contracts }\end{array}$ & Public housing & $\begin{array}{l}\text { Pre-university } \\
\text { education }\end{array}$ & $\begin{array}{l}\text { University } \\
\text { education }\end{array}$ \\
\hline Accra & 27.8 & 27.8 & 39.5 & 18.6 & 15.4 \\
Ho & 24.6 & 23.0 & 27.9 & 19.7 & 14.8 \\
Kumasi & 15.8 & 14.9 & 30.7 & 10.0 & 7.1 \\
\hline
\end{tabular}

Table 14: The proportion of Nigerian respondents according to survey location who thought that religion affected someone's chances of getting ...

\begin{tabular}{|l|lllll|}
\hline & Government jobs & $\begin{array}{l}\text { Government } \\
\text { contracts }\end{array}$ & Public housing & $\begin{array}{l}\text { Pre-university } \\
\text { education }\end{array}$ & $\begin{array}{l}\text { University } \\
\text { education }\end{array}$ \\
\hline Ajegunle Lagos & 28.4 & 30.3 & 26.8 & 27.3 & 29.8 \\
Lagos Island & 33.0 & 28.4 & 18.0 & 22.7 & 23.7 \\
Kukawa & 24.0 & 23.0 & 21.5 & 18.5 & 18.5 \\
\hline
\end{tabular}

Another interesting finding in the Nigerian survey was that the Christian respondents were more concerned about the impact of religion than the Muslim respondents in the Lagos Island sample, while the Muslim respondents were more concerned than the Christian respondents in the Ajegunle sample. Taking into account that the Ajegunle sample had a Christian majority, while the Lagos Island sample was dominated by Muslims, this finding (like the first one) suggests that the religious composition of a survey location influenced respondents' perceptions of the impact of religion in the public sphere.

\section{Perceptions of political horizontal inequalities}

In this section, we aim to assess the perceived horizontal inequalities in the politicaladministrative sphere by analyzing respondents' perceptions of which groups dominate the national/federal government, the top-level of the police, the top-level of the civil service, the top-level of the armed forces and the judiciary. The relevant question in the perceptions questionnaire was two-pronged. Respondents were asked whether they thought a certain group of people (without mentioning any particular group) dominated a particular state institution; if respondents answered 'yes' to this, they were asked to name the dominant group(s) of people. The results are shown in Tables 15 and 16.

In the Ghanaian survey, Table 15 shows that there were significant differences between the three survey locations. While the respondents in Accra and Kumasi had very similar perceptions regarding the alleged domination of the main state institutions, a considerably higher proportion of the respondents in Ho perceived the different state institutions to be dominated by certain groups of people. Nonetheless, with the exception of the national government, the proportion of respondents who perceived the different state institutions to be dominated by certain groups was relatively moderate, particularly in Accra and Kumasi. Moreover, the groups which were perceived to dominate the national government were extremely diverse, including 'lawyers', 'NPP party members', 'president's relatives' and 'Christians'. But more respondents in Ho perceived ethnic domination of the national government. About 51 per cent of them mentioned the Akan or a sub-group thereof (particularly the Ashanti) as the dominant group in the national government. And while the Akan were also the most frequently mentioned group in the other two cities, overall only about 28 per cent and 25 per cent of the respondents in Accra and Kumasi 
respectively perceived this ethnic group to dominate the national government. Interestingly, the proportion of the Mole-Dagbani respondents in the Kumasi sample, used here as our 'northern' proxy, who perceived these five state institutions to be dominated by a particular group was consistently smaller than that of the Akan respondents in Kumasi. While about 26 per cent of the Mole-Dagbani respondents perceived the national government to be dominated by a particular group, with regard to the police and armed forces it was 22 per cent, and with regard to the civil service and judiciary it was only 19 per cent.

Table 15: The proportion of Ghanaian respondents according to survey location who considered a specific state institution to be dominated by a particular group

\begin{tabular}{|l|lllll|}
\hline & $\begin{array}{l}\text { National } \\
\text { Government }\end{array}$ & $\begin{array}{l}\text { Top-level of the } \\
\text { police }\end{array}$ & $\begin{array}{l}\text { Top-level } \\
\text { civil service }\end{array}$ & $\begin{array}{l}\text { Top-level of the } \\
\text { armed forces }\end{array}$ & Judiciary \\
\hline Accra & 39.5 & 29.1 & 23.9 & 24.2 & 19.3 \\
Ho & 65.6 & 41.0 & 31.1 & 41.0 & 24.6 \\
Kumasi & 38.2 & 31.5 & 20.7 & 25.7 & 22.8 \\
\hline
\end{tabular}

Table 16: The proportion of Nigerian respondents according to survey location who considered a specific state institution to be dominated by a particular group

\begin{tabular}{|l|lllll|}
\hline & $\begin{array}{l}\text { Federal } \\
\text { Government }\end{array}$ & $\begin{array}{l}\text { Top-level of the } \\
\text { police }\end{array}$ & $\begin{array}{l}\text { Top-level } \\
\text { civil service }\end{array}$ & $\begin{array}{l}\text { of } \\
\text { armed forces }\end{array}$ & Judiciary \\
\hline Ajegunle Lagos & 52.0 & 34.5 & 37.9 & 56.1 & 25.5 \\
Lagos Island & 64.2 & 41.6 & 37.2 & 62.2 & 40.9 \\
Kukawa & 24.5 & 22.5 & 21.5 & 18.0 & 29.0 \\
\hline
\end{tabular}

According to the Nigerian survey, a significantly larger proportion of respondents in the Lagos survey locations perceived the different state institutions to be dominated by certain groups of people (see Table 16). In addition to the federal government, the top-level of the armed forces was a second state institution which a large proportion of Nigerian respondents perceived to be dominated by particular groups. However, a relatively high number of respondents answered that they did not know whether or not a particular group dominated the different state institutions. Thus, for instance, with regard to the federal government, 33 per cent, 26 per cent and 61 per cent of the respondents in Ajegunle, Lagos Island and Kukawa respectively answered that they did not know whether a particular group of people dominated this level of government. In the Ghanaian survey, the proportion of respondents who mentioned 'Don't know' when they were asked whether the national government was dominated by a particular group of people, was considerably smaller (between 12-15 per cent). It is difficult to determine whether the high proportion of respondents who answered 'Don't know' in the Nigerian survey was the result of lack of knowledge, or whether respondents were reluctant to answer the question because of the sensitive nature of the issues involved. Nonetheless, the fact that the largest percentage of 'Don't know' responses was recorded in Kukawa which had the lowest proportion of educated respondents may indicate that lack of knowledge was a crucial factor.

Notwithstanding the high proportion of 'Don't know' responses, it is interesting to note that the vast majority of respondents who perceived the federal government and the top-level of the armed forces to be dominated by a certain group mentioned either the Yoruba or the Hausa-Fulani. In the two survey locations in Lagos, the most frequently mentioned ethnic group perceived to dominate the federal government was the Hausa-Fulani. While about 29 per cent of the respondents in Ajegunle perceived the Hausa-Fulani as the dominant group in the federal government, in Lagos Island this was 47 per cent. Only between $23-26$ per cent of the respondents 
in Ajegunle and Lagos Island perceived the Yoruba to dominate the federal government. The finding that a relatively higher proportion of respondents perceived the Hausa-Fulani to dominate the federal government in both the ethnically diverse survey location of Ajegunle and the Yoruba-dominated survey location of Lagos Island is all the more intriguing if one considers that the president of Nigeria at the time that the survey was conducted, Olusegun Obasanjo, was a Yoruba. In contrast to the survey locations in Lagos, the Yoruba were indeed the most frequently mentioned ethnic group perceived to dominate the federal government in the Kukawa sample (around 17 per cent of the respondents mentioned them).

With regard to the top-level of the armed forces, about 48 per cent and 62 per cent of the respondents in Ajegunle and Lagos-Island respectively perceived the HausaFulani to dominate this state institution. In Kukawa, which has a large Hausa-Fulani population, only about 3 per cent of the respondents perceived the armed forces to be dominated by the Hausa-Fulani, while about 14 per cent of the respondents again mentioned the Yoruba as the dominant group. Moreover, even though a much larger proportion of respondents in the Nigerian survey was unable or possibly reluctant to answer whether certain groups dominated a particular state institution, it emerged that a relatively higher proportion of respondents in the Nigerian survey perceived the most important state institutions to be dominated by certain ethnic groups than in the Ghanaian survey. This could be taken as further evidence of the more politicised nature of ethnicity in Nigeria than in Ghana.

\section{Perceptions of government favouritism and discrimination}

A final issue which is extremely relevant for assessing the functioning of the Ghanaian and Nigerian state deals with respondents' perceptions of government favouritism and discrimination. The relevant question in the perceptions questionnaire was also two-pronged. Respondents were asked whether or not they thought that certain groups of people were favoured or discriminated against by the government. If they answered 'yes' to this, they were subsequently asked to name the groups of people that they perceived to be favoured or discriminated against by the government. Tables 17 and 18 show the proportion of respondents in Ghana and Nigeria who perceived there to be government favouritism or discrimination against certain groups of people.

Table 17: Perceptions of government favouritism and discrimination in Ghana according to survey location

\begin{tabular}{|l|l|l|}
\hline & Favouritism & Discrimination \\
\hline Accra & 31.4 & 20.6 \\
Ho & 47.5 & 45.9 \\
Kumasi & 19.5 & 13.7 \\
\hline
\end{tabular}

Table 18: Perceptions of government favouritism and discrimination in Nigeria according to survey location

\begin{tabular}{|l|l|l|}
\hline & Favouritism & Discrimination \\
\hline Ajegunle Lagos & 48.0 & 34.8 \\
Lagos Island & 51.5 & 35.1 \\
Kukawa & 29.5 & 21.0 \\
\hline
\end{tabular}


With regard to the Ghanaian survey, there were significant differences between the three survey locations regarding the extent of perceived favouritism or discrimination by government. In all three survey locations it emerged that the proportion of respondents who perceived the government to favour certain groups was noticeably higher than the proportion of respondents who perceived certain groups to be discriminated against by the government. Again respondents in $\mathrm{Ho}$ and Kumasi appeared to have the most divergent perceptions regarding these issues, while respondents in Accra had overall views that fell once more somewhere in between these two. Although respondents' perceptions of the particular groups favoured or discriminated against by the government were again extremely diverse, including such categories as 'the young and wise,' 'relatives and friends of government officials,' 'the rich' and 'students', most respondents who thought there was government favouritism and/or discrimination mentioned a particular ethnic group. The respondents in $\mathrm{Ho}$, in particular, claimed there was favouritism and discrimination by government on ethnic grounds. While 33 per cent of the Ho respondents perceived the Akan or a sub-group thereof (particularly the Ashanti) to be favoured by the government, about 19 per cent of them perceived the Ewe to be discriminated against by the Kufuor government. The proportion of respondents in the other two cities who perceived the Akan (or a sub-group thereof) to be favoured by the government was significantly lower; in particular 8 per cent and 17 per cent of the respondents in Kumasi and Accra respectively mentioned the Akan. Moreover, only one respondent in the whole survey perceived the Akan to be discriminated against by the Kufuor government.

As already mentioned, the differences between the respondents in Ho and Kumasi also tell us something about the differences in perceptions between the Ewe and Akan respondents in our survey. In this respect it is important to note that since the emergence of Ghana's Fourth Republic in January 1993, the Ewe and Akan, particularly the Ashanti, have persistently supported opposing political parties. While the Ewe generally support the National Democratic Congress (NDC), which was founded by former military dictator and civilian president Jerry Rawlings (who is halfEwe himself), the Ashanti/Akan have given most support to the NPP. The voting patterns in both ethnic groups' home regions -i.e. the Ashanti and Volta regionsillustrate this political divide strikingly. In particular, in all four general elections that were held in Ghana's Fourth Republic, the NPP persistently won by a huge majority in the Ashanti Region, while the NDC swept most of the votes in the Volta Region. The persistence of differences in Ewe-Ashanti/Akan voting patterns has contributed to the view that the NPP and NDC are largely Akan-based and Ewe-based political parties. Moreover, considering that the NPP is currently in power, it should not come as a surprise that a significant minority of the Ewe/Ho respondents perceived the Kufuor government to favour the Akan.

With regard to the extent of government favouritism and discrimination in Nigeria, there was again a clear north-south divide in perceptions. In particular, perceptions of government favouritism and discrimination were considerably more widespread among respondents in the two Lagos survey locations than in Kukawa. The most frequently mentioned group perceived to be favoured by the government were the Hausa-Fulani: about 28 per cent and 38 per cent of the respondents in Ajegunle and Lagos Island respectively perceived this ethnic group to be favoured by the government. Conversely, only around 18-19 per cent of the respondents in the Lagos survey locations mentioned the Yoruba in this respect. In Kukawa, an even smaller proportion of respondents (around 9 per cent) perceived there to be Yoruba favouritism. 
Like in Ghana, the proportion of respondents in all survey locations who perceived there was favouritism by government was considerably higher than those who thought that the government discriminated against particular groups. Only a very small proportion of respondents in the Nigerian survey perceived that the Yoruba or Hausa-Fulani were discriminated against by the government. The most frequently mentioned group in both Ajegunle and Lagos-Island perceived to be discriminated against by the government was the Igbo (about 13-14 per cent of the respondents mentioned them). Most of the respondents who perceived the lgbo to be discriminated against were Igbo themselves. In order to understand why a significant proportion of lgbo respondents felt discriminated against by the government, one has to take into account the fact that while they dominated the civil service in the early years of independence, following the Nigerian civil war they became marginalised in Nigeria's main state institutions. Moreover, although they constitute one of the three major ethnic groups, they have produced the head of government for a period of only six months whereas the Hausa/Fulani and Yoruba have produced long serving heads of government. The alleged marginalization of the Igbo in Nigeria's political decisionmaking bodies is likely to have been an important factor in fostering these feelings of government discrimination among a significant minority of the Igbo (Mustapha, 2005).

\section{Conclusions}

The surveys showed quite marked differences between Ghana and Nigeria, although we must exercise caution in making generalizations based on the limited sample and different selection strategies. We found that while more Nigerian than Ghanaian respondents perceived religious and ethno-regional/linguistic identities among their three most important identities, the reverse was the case with regard to occupation and nationality. Ghanaian respondents generally tended to value their national and occupational identities more than Nigerian respondents did. Moreover, more respondents in Nigeria than in Ghana believed that ethnicity affected access to public goods and that the government shows favouritism and discrimination.

Interestingly, contrary to the modernization perspective on ethnicity and national integration, attainment of higher levels of education did not diminish the tendency for people to think in ethnic terms. On the contrary, both the Ghanaian and Nigerian survey reaffirmed Melson and Wolpe's (1971) findings that educational attainment and other attributes of modernization are positively correlated with greater salience of ethnic identities and perceptions of favouritism on ethnic grounds. As we have argued in this respect, this is probably because it is those with higher educational attainments that compete for the most lucrative jobs and business opportunities and therefore know where the shoes pinch.

Both Ghana and Nigeria have had turbulent political histories characterised by frequent military coups. However, while Nigeria has gone through a civil war and has been confronted by recurrent ethnic and religious violence especially since the late 1980s, Ghana, has so far, with the exception of communal conflicts in its northern regions, avoided serious inter-ethnic and religious violence. The differences in comparative perceptions of identities and of perceptions of the state in Ghana and Nigeria may help explain why Nigeria has been more prone to violent conflict than Ghana. But we should note that the causality could also go the other way, from a more violent environment to greater perceptions of ethnic salience and discrimination. In addition there are other reasons for the difference in the political salience of ethnic identities in the two countries such as the adoption of quotas for jobs according to regional origin in Nigeria. Such quotas and the related practice of 
the federal character principle, which also involves ensuring that different major ethnic groups are represented at many levels in the political system and the bureaucracy, may explain why ethno-linguistic and regional identities remain strong in Nigeria. At the same time, however, these policies were introduced precisely because ethnicity appeared to be so politically salient (Mustapha, 2005).

A comparison of the 'objective' socioeconomic and political horizontal inequalities in both countries (see Tables 1-4) with respondents' perceptions of the impact of ethnic or religious identities on getting access to educational opportunities (see Tables 9-10 and 13-14) as well as the extent of domination of different state institutions by particular groups (see Tables 15-16), proves interesting in two respects. Firstly, in Nigeria, even though the school enrolment rates are drastically lower in the Northeastern zone (where Kukawa is located), paradoxically, respondents in the two Lagos survey sites were much more concerned about the impact of ethnicity but also religion on getting educational opportunities particularly. In the Ghanaian survey, while using the Mole-Dagbani respondents in the Kumasi sample as a proxy for the perceptions of the northerners, a similar finding emerged. A possible explanation for this apparent 'paradox' could be that respondents' perceptions of the impact of ethnic or religious background on educational opportunities are based on experiences within the region or locality in which they live, while the recorded educational differences were between regions.

Secondly, the comparison of the 'objective' and perceived political horizontal inequalities in the Ghanaian case shows that respondents belonging to the politically dominant ethnic group in objective terms (the Akan) were much less likely to perceive this political reality than the objectively under-represented ethnic group(s) (the Ewe) to perceive themselves as underrepresented. In Nigeria, a somewhat different but related finding emerges: respondents of the two major ethnic groups in terms of objective political representation, the Hausa-Fulani and Yoruba, tended to perceive the other group as the dominant one. Both cases illustrate the finding that where you stand determines what you see. 


\section{References}

Deutsch, K. 1961 'Social Mobilization and Political Development', American Political Science Review 55: 493-514.

Guichaoua, Y., Langer, A., Mancini, L., Stewart, F. and Ukiwo, U. 2006 'The role of ethnicity in conflicts: results of a perceptions questionnaire in Ghana and Nigeria' CEMISS Final Report, Oxford: Centre for Research on Inequality, Human Security and Ethnicity (CRISE), University of Oxford.

Gyimah-Boadi, E. and Asante, R. 2006 'Ethnic Structure, Inequality and Public Sector Governance in Ghana', in Y. Bangura (ed) Ethnic Inequalities and Public Sector Governance, Basingstoke: Palgrave Macmillan.

Laitin, D. D. 1986 Hegemony and Culture: Politics and Religious Change among the Yoruba, Chicago University of Chicago Press.

Langer, A. 2006 'Political horizontal inequalities in Ghana', CRISE Internal Paper Oxford: Centre for Research on Inequality, Human Security and Ethnicity (CRISE).

- 2007 'The peaceful management of horizontal inequalities in Ghana', CRISE Working Paper No. 25, Oxford: Centre for Research on Inequality, Human Security and Ethnicity, University of Oxford.

Langer, A., Mustapha, A. R. and Stewart, F. 2007 'Horizontal Inequalities in Nigeria, Ghana and Côte d'Ivoire: Issues and Policies', CRISE Working Paper No. 45, Oxford: Centre for Research on Inequality, Human Security and Ethnicity, University of Oxford.

Melson, R. and Wolpe, H. 1971 'Modernization and the Politics of Communalism: A Theoretical Perspective', in R. Melson and H. Wolpe (eds) Nigeria: Modernization and the Politics of Communalism, East Lansing: Michigan State University Press.

Mustapha, R. 2005 'Ethnic Structure, Inequality and Governance of the Public Sector in Nigeria ', CRISE Working Paper No. 18, Oxford: Centre for Research on Inequality, Human Security and Ethnicity, University of Oxford.

Otite, O. 1990 Ethnic Pluralism and Ethnicity in Nigeria, Ibadan: Shaneson C.I.

Shepherd, A., Gyimah-Boadi, E., Gariba, S., Plagerson, S. and Musa, W. A. 2005 'Bridging the north south divide in Ghana? Background Paper for the 2006 World Development Report' World Development Report 2006: Equity \& Development.

Songsore, J. 2003 Regional development in Ghana: The theory and the reality, Accra: Woeli Publishing Services.

Stewart, F. (ed) Forthcoming Horizontal Inequalities and Conflict: Understanding Group Violence in Multiethnic Countries, London: Palgrave. 